\title{
Knee ultrasound from research to real practice: a systematic literature review of adult knee ultrasound assessment feasibility studies
}

\author{
Alexandra Peltea*, Florian Berghea*, Tania Gudu, Ruxandra Ionescu
}

"Sf. Maria" Clinical Hospital, Research Centre on the Pathology and Treatment of Systemic Rheumatic Diseases, Internal Medicine and Rheumatology department "Carol Davila" University of Medicine and Pharmacy, Bucharest, Romania *both authors contributed equally to this paper

\begin{abstract}
Aim: To identify and analyse existing data regarding knee ultrasound (US) feasibility in clinical practice. Material and methods: A systematic literature review was performed using the terms: ("knee") AND ("ultrasound" OR "ultrasonography") AND ("feasibility" OR "pilot" OR "proof of concept"). Feasibility studies regarding knee US or US aided maneuver involving knee joint, published during 2005-2015, were selected and evaluated against a complex framework constructed around mandatory key areas for feasibility studies: acceptability, demand, implementation, practicality, adaptation, integration and expansion. Results: One hundred and fifty-nine publications were identified, of which 9 were included in the final analysis: 6 dealt with the development and implementation of novel US scores, while the rest focused on implementing MSUS in clinical practice, evaluating the usefulness of articular cartilage US assessment and the feasibility of sonography for intra-articular knee injections, respectively. Six studies quantified feasibility as time spent for the evaluation, with only two addressing areas such as acceptability, implementation and practicality, although none of these systematically assessed all feasibility domains. Conclusion: Knee US feasibility is still poorly addressed; the time required for US assessment is the main area addressed. This information gap should be properly addressed in future works, in order to ensure the right place for this technique.
\end{abstract}

Keywords: feasibility studies, ultrasonography, knee

\section{Introduction}

Musculoskeletal ultrasound (MSUS) has been gaining an increasingly important role in rheumatology, as a non-invasive and accessible imaging method [1], mainly due to its increased sensitivity compared to clinical examination for detecting synovial thickening or joint effusion [2]. However, even if its usefulness has been extensively evaluated among rheumatologists, several barriers limit its implementation in daily practice: the availability of a good quality machine or an experienced sonographer are just two such barriers [3].

An increasing number of papers focused on MSUS techniques or disease activity scores assessed with

Received 25.07.2016 Accepted 31.08.2016

Med Ultrason

2016, Vol. 18, No 4, 457-462

Corresponding author: Florian Berghea

Sf. Maria Hospital

37-39 Ion Mihalache Bd.

011172 Bucharest, Romania

E-mail: berghea1@gmail.com
MSUS have been published over the last years; their scientific quality also has improved, so there is evidence of a high uptake of MSUS in most European countries [4]. However, the authors appear to have paid less attention to feasibility aspects concerning its utilisation in the clinical setting.

Although a general definition of a "feasibility study" can be found after a quick search on the internet - "an analysis of the ability to complete a project successfully, taking into account legal, economic, technological, scheduling and other factors" [5], a standardised framework for the design of a medical feasibility study, particularly for the evaluation of MSUS feasibility still has not a consensus.

For many authors, there is not a clear difference between "feasibility" and "pilot" studies. Lancaster et al [6] conducted a review of the seven most important medical journals in 2000-2001, using 'pilot' and 'feasibility' as keywords; the authors focused mainly on pilot studies used to plan Randomised Clinical Trials, thus making no general recommendations for a feasibility study. The 
difference between the requirements of pilot studies and feasibility studies was brought up by Arain et al [7] later, in a 2010 review of the same medical journals used by Lancaster et al. Their conclusion was that, in practice, the definitions of 'feasibility' and 'pilot' studies are not distinct, suggesting the use of the NETSCC definition (United Kingdom's National Institute for Health Research Evaluation, Trials and Studies Coordination Centre; 2012), which defines feasibility studies as "pieces of research done before a main study in order to answer the question 'Can this study be done?'... used to estimate important parameters that are needed to design the main study" (Research Methods section, paragraph 3).

Moreover, previous work by Tickle-Degnen et al has also suggested that the outcomes of most feasibility studies are measured using descriptive statistics and qualitative analysis, including data regarding administrative and physical infrastructure [8]. Bowen et al [9] concluded different types of feasibility studies conducted in the field of cancer prevention and suggested a methodology developed in compliance with the NETSCC definition; we considered their methodology largely suitable for the assessment of MSUS feasibility studies.

In our work we intended to verify to what depth are feasibility aspects assessed in knee related MSUS papers.

\section{Material and methods}

A systematic literature search of the PubMed/Medline and Web of Science (Thomson Reuters) databases was conducted on December 20 $0^{\text {th }}$ 2015. Publications were identified using the following terms: ("knee") AND ("ultrasound" OR "ultrasonography") AND ("feasibility" OR "pilot" OR "proof of concept"), within the 2005-2015 timeframe. We also looked for any available proceeding in the European League Against Rheumatism and American College of Rheumatology Annual Meetings databases for the same period, as well as references of the selected works. The inclusion criteria comprised studies evaluating knee US or the feasibility of US aided interventions, unless they included a surgical intervention. We excluded studies that only assessed the accuracy, reliability or validity of US, as well as studies validating US scores that did not include the knee, reviews, non-English studies and articles concerning the paediatric population. The selected process is depicted in figure 1 and the papers are listed in Table I.

In addition, we searched the literature for guidelines regarding feasibility studies and we selected the most comprehensive list of focus areas to be addressed [9]. For our analysis of the selected papers, we assumed 7 mandatory key areas (Table II)(1)Acceptability: this domain

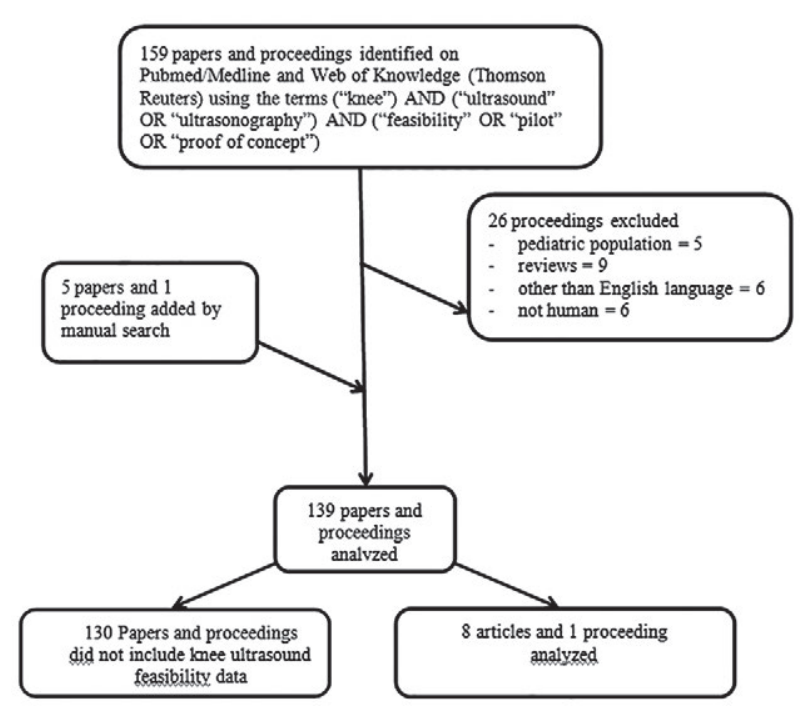

Fig 1. Flowchart of article selection.

assesses how both medics and patients react to MSUS, in terms of how suitable, satisfying or attractive US evaluation is. (2) Demand: data regarding estimated use (patient and medic expressed interest) or actual use of MSUS in clinical setting. (3) Implementation: evaluation of the success and quality of MSUS, as well as the amount and type of resources required to perform the evaluation. (4) Practicality: refers to factors that influence the speed, efficiency or the quality of MSUS implementation, the effect on patients and the ability of medics to perform MSUS, along with a cost analysis. (5) Adaptation: evaluates to what extent MSUS performs when used for different pathologies or joints. (6) Integration: assesses the perceived fit with infrastructure (organizational setting or the social/physical environment) and the sustainability of MSUS. (7) Expansion: evaluates the potential success of using MSUS in a different setting (guided interventions, score development, assessment of non-MS structures).

Other aspects that might influence feasibility, such as machine characteristics, assessor's level of training and use of standardized scoring systems, were considered as well.

Each of the papers included in the final analysis scored 1 point for every domain of interest addressed and 0 points for omitting it, in order to allow a more objective assessment of these publications (Table II).

\section{Results}

\section{Systematic literature review}

In all, 159 publications were identified through the systematic search of the databases, with 6 more works added to these after the manual search: 7 original articles and 2 
Table I. Summary of the selected articles

\begin{tabular}{|c|c|c|c|c|}
\hline $\begin{array}{l}\text { Studies selected } \\
\text { for analysis }\end{array}$ & $\begin{array}{l}\text { Disease } \\
\text { studied }\end{array}$ & $\begin{array}{l}\text { Equipment and technical char- } \\
\text { acteristics }\end{array}$ & $\begin{array}{l}\text { Number of patients } \\
\text { and mean age }\end{array}$ & $\begin{array}{l}\text { Assessed joints and } \\
\text { features/structures }\end{array}$ \\
\hline $\begin{array}{l}\text { 1. Gulati et al } 2015 \\
\text { [10] }\end{array}$ & $\begin{array}{l}\text { Not men- } \\
\text { tioned }\end{array}$ & Not mentioned & $\begin{array}{l}15 \text { residents; number } \\
\text { of patients not men- } \\
\text { tioned } \\
\text { Age not mentioned }\end{array}$ & $\begin{array}{l}\text { Joints: knee } \\
\text { Features/structures: knee effusion }\end{array}$ \\
\hline $\begin{array}{l}\text { 2. Peiteado et al } \\
2012[11] \\
\text { (no full text avail- } \\
\text { able) }\end{array}$ & Gout & Not mentioned & $\begin{array}{l}29(27 \text { men }) \\
\text { Age not mentioned }\end{array}$ & $\begin{array}{l}\text { Joints: } 1^{\text {st }} \text { MTP, knee - bilaterally } \\
\text { Features/structures: } \\
\text { - hyperechoic spots in the synovial } \\
\text { fluid } \\
\text { - hyperechoic cloudy areas } \\
\text { - bright stippled aggregates } \\
\text { - the double contour sign } \\
\text { - erosions } \\
\text { - Doppler signal }\end{array}$ \\
\hline $\begin{array}{l}\text { 3. Perricone et al } \\
2012[12]\end{array}$ & RA & $\begin{array}{l}\text { MyLab70 XVisionGold (Esaote, } \\
\text { Firenze, Italy) } \\
\text { transducer 6-18 MHz } \\
\text { PD PRF } 750 \mathrm{~Hz} \\
\text { Doppler frequency } 6.7-11.1 \mathrm{MHz} \\
\text { low wall filters }\end{array}$ & $\begin{array}{l}45(8 \text { men, } 37 \\
\text { women) } \\
638.5(\text { SD 173.4) } \\
\text { months }\end{array}$ & $\begin{array}{l}\text { Joints: elbow, wrist, } 2^{\text {nd }} \mathrm{MCP}, 3^{\text {rd }} \\
\text { MCP, knee and ankle - bilaterally } \\
\text { Features/structures: } \\
\text { - synovial effusion and/or prolifera- } \\
\text { tion } \\
\text { - PD }\end{array}$ \\
\hline $\begin{array}{l}\text { 4. Ohashi et al } 2012 \\
\text { [13] } \\
\text { (no full text avail- } \\
\text { able) }\end{array}$ & $\begin{array}{l}\text { OA and } \\
\text { healthy } \\
\text { controls }\end{array}$ & $\begin{array}{l}\text { B-mode US: knee flexed at } 120^{\circ} \\
\text { MRI of the knees: double echo } \\
\text { steady-state sequence. }\end{array}$ & $\begin{array}{l}3 \text { OA men }(73,81 \\
\text { and } 83 \text { years) and } 2 \\
\text { healthy men ( } 37 \text { and } \\
59 \text { years) }\end{array}$ & $\begin{array}{l}\text { Joints: Medial surface healthy right } \\
\text { knee and affected OA knee } \\
\text { Features/structures: Tc - determined } \\
\text { at points } 1 \mathrm{~mm} \text { apart from one an- } \\
\text { other in the US and MRI models }\end{array}$ \\
\hline $\begin{array}{l}\text { 5. Im et al } 2009 \\
{[14]}\end{array}$ & OA & $\begin{array}{l}\text { Knee MRI } \\
\text { US machine (L12-5/38 mm, } \\
\text { HDI 5000; Philips Healthcare, } \\
\text { Bothell, WA) } \\
\text { 7-12-MHz linear array probe } \\
\text { Knee X-ray }\end{array}$ & $\begin{array}{l}89: 45 \text { US guided vs. } \\
44 \text { blind injection } \\
\text { Male/Female: } 11 / 34 \\
\text { vs. } 13 / 31 \\
60.6(7.9) \text { years vs. } \\
59.6(9.9) \text { years }\end{array}$ & $\begin{array}{l}\text { Joints: Affected knee - medial patel- } \\
\text { lar portal } \\
\text { Features/structures: } \\
\text { - Supine with extended knee for US } \\
\text { guided injection } \\
\text { - Medial fat pad measurement }\end{array}$ \\
\hline $\begin{array}{l}\text { 6. Ficjan et al } 2014 \\
{[15]}\end{array}$ & PsA & $\begin{array}{l}\text { MyLab Twice ultrasound device } \\
\text { (Esaote, Genova, Italy) } \\
\text { two multifrequence lin- } \\
\text { ear transducers (6-18 MHz and } \\
\text { 4-13 MHz). }\end{array}$ & $\begin{array}{l}83 \text { (22 females) } \\
51.8 \text { (SD 11.7) years }\end{array}$ & $\begin{array}{l}\text { Joints: } 68 \text { joints and } 14 \text { entheses } \\
\text { Features/structures: } \\
\text { - GS and PD } \\
\text { - synovitis, tenosynovitis, erosions, } \\
\text { osteophytes, enthesitis }\end{array}$ \\
\hline $\begin{array}{l}\text { 7. Aga et al } 2014 \\
\text { [16] } \\
\text { (no full text avail- } \\
\text { able) }\end{array}$ & RA & Not mentioned & $\begin{array}{l}230 \text { early RA and } 212 \\
\text { established RA } \\
\text { Age not mentioned }\end{array}$ & $\begin{array}{l}\text { Joints: } 36 \text { joints - MCP 1-5, PIP } \\
\text { 2-3, RC, distal RU, intercarpal, } \\
\text { elbow, knee, talocrural and MTP 1-5 } \\
\text { bilaterally } \\
\text { Features/structures: GS and PD } \\
\text { semi-quantitative scoring system }\end{array}$ \\
\hline $\begin{array}{l}\text { 8. Hartung et al } \\
2011[17]\end{array}$ & RA & Not mentioned & $\begin{array}{l}199 \\
\text { Age not mentioned }\end{array}$ & $\begin{array}{l}\text { Joints: Not mentioned } \\
\text { Features/structures: GS and PD }\end{array}$ \\
\hline $\begin{array}{l}\text { 9. Naredo et al } 2008 \\
{[18]}\end{array}$ & RA & $\begin{array}{l}\text { Logiq } 5 \text { PRO; GE } \\
\text { Healthcare, Kyunnggi-do, Korea } \\
7-12 \mathrm{MHz} \text { linear array transduc- } \\
\text { ers }\end{array}$ & $\begin{array}{l}160(125 \text { women, } 35 \\
\text { men) } \\
54.1(\text { SD } 12.4) \text { years }\end{array}$ & $\begin{array}{l}\text { Joints: } 44 \text { joints (bilateral shoulder, } \\
\text { elbow, wrist, MCP, PIP, hip, knee, } \\
\text { ankle, tarsal and MTP) } \\
\text { Features/structures: GS and PD }\end{array}$ \\
\hline
\end{tabular}

$\mathrm{SD}$ - standard deviation; RA - rheumatoid arthritis; PsA - psoriatic arthritis; OA - osteoarthritis; Tc - thickness of cartilage; RC - radiocarpal joint; RU - radioulnar joint; MCP - metacarpophalangeal joint; PIP - proximal interphalangeal joint; MTP - metatarsophalangeal joint; MRI - magnetic resonance imaging; US - ultrasonography; GS - gray scale; PD - power Doppler; B-mode - brightness mode; PRF - pulse repetition frequency 
Table II. Key areas of focus for feasibility studies (modified after Bowen et al [8]).

\begin{tabular}{|c|c|c|c|c|c|c|c|c|c|c|c|}
\hline \multirow[t]{2}{*}{ Area of focus } & \multirow[t]{2}{*}{$\begin{array}{l}\text { The feasibility study } \\
\text { asks ... }\end{array}$} & \multirow[t]{2}{*}{ Sample outcomes of interest } & \multicolumn{9}{|c|}{$\begin{array}{l}\text { Article scoring: } \\
1 \text { - area of focus addressed } \\
0 \text { - area of focus omitted }\end{array}$} \\
\hline & & & S1 & S2 & S3 & S4 & S5 & S6 & S7 & S8 & S9 \\
\hline Acceptability & $\begin{array}{l}\text { To what extent is } \\
\text { knee ultrasound } \\
\text { judged as suitable, } \\
\text { satisfying or attrac- } \\
\text { tive to medics? To } \\
\text { patients? }\end{array}$ & $\begin{array}{l}\text { Satisfaction } \\
\text { Intent to continue use } \\
\text { Perceived appropriateness }\end{array}$ & 1 & 0 & 0 & 0 & 0 & 0 & 0 & 0 & 0 \\
\hline Demand & $\begin{array}{l}\text { To what extent is } \\
\text { knee ultrasound } \\
\text { likely to be used } \\
\text { (i.e. how much } \\
\text { demand is likely to } \\
\text { exist?) }\end{array}$ & $\begin{array}{l}\text { Fit within organizational } \\
\text { culture } \\
\text { Perceived positive or negative } \\
\text { effects on organization } \\
\text { Actual use } \\
\text { Expressed interest or intention } \\
\text { to use } \\
\text { Perceived demand }\end{array}$ & 1 & 1 & 0 & 0 & 0 & 1 & 1 & 1 & 1 \\
\hline Implementation & $\begin{array}{l}\text { To what extent can } \\
\text { knee ultrasound } \\
\text { be successfully } \\
\text { delivered to patients } \\
\text { in daily clinical } \\
\text { practice? }\end{array}$ & $\begin{array}{l}\text { Degree of execution } \\
\text { Success or failure of execution } \\
\text { Amount, type of resources } \\
\text { needed to implement }\end{array}$ & 1 & 1 & 1 & 1 & 1 & 1 & 0 & 1 & 1 \\
\hline Practicality & $\begin{array}{l}\text { To what extent can } \\
\text { knee ultrasound be } \\
\text { carried out with pa- } \\
\text { tients using existing } \\
\text { means, resources, } \\
\text { circumstances, and } \\
\text { without outside } \\
\text { intervention? }\end{array}$ & $\begin{array}{l}\text { Factors affecting implementa- } \\
\text { tion ease or difficulty } \\
\text { Efficiency, speed, or quality of } \\
\text { implementation } \\
\text { Positive/negative effects on } \\
\text { target participants } \\
\text { Ability of participants to carry } \\
\text { out intervention activities } \\
\text { Cost analysis }\end{array}$ & 0 & 1 & 1 & 0 & 1 & 1 & 1 & 1 & 1 \\
\hline Adaptation & $\begin{array}{l}\text { To what extent does } \\
\text { knee ultrasound per- } \\
\text { form when changes } \\
\text { are made for a new } \\
\text { format or with a dif- } \\
\text { ferent pathology? }\end{array}$ & $\begin{array}{l}\text { Degree to which similar } \\
\text { outcomes are obtained in new } \\
\text { format (different joint) } \\
\text { Process outcomes comparison } \\
\text { between intervention use in } \\
\text { two populations (different } \\
\text { pathologies) }\end{array}$ & 0 & 0 & 0 & 0 & 0 & 0 & 0 & 0 & 0 \\
\hline Integration & $\begin{array}{l}\text { To what extent can } \\
\text { knee ultrasound be } \\
\text { integrated within the } \\
\text { existing system? }\end{array}$ & $\begin{array}{l}\text { Perceived fit with infrastructure } \\
\text { Perceived sustainability }\end{array}$ & 0 & 0 & 0 & 0 & 0 & 0 & 0 & 0 & 0 \\
\hline Expansion & $\begin{array}{l}\text { To what extent } \\
\text { can ultrasound be } \\
\text { expanded to provide } \\
\text { a new program or } \\
\text { service? }\end{array}$ & $\begin{array}{l}\text { Costs to organization and } \\
\text { policy bodies } \\
\text { Fit with organizational goals } \\
\text { and culture } \\
\text { Positive or negative effects on } \\
\text { organization } \\
\text { Disruption due to expansion } \\
\text { component }\end{array}$ & 0 & 0 & 0 & 0 & 0 & 0 & 0 & 0 & 0 \\
\hline & & Total score & 3 & 3 & 3 & 1 & 2 & 3 & 1 & 3 & 3 \\
\hline
\end{tabular}

S1 - Gulati et al 2015 [10], S2 - Peiteado et al 2012 [11], S3 - Perricone et al 2012 [12], S4 - Ohashi et al 2012 [13], S5 - Im et al 2009 [14], S6 - Ficjan et al 2014 [15], S7 - Aga et al 2014 [16], S8 - Hartung et al 2011 [17], S9 - Naredo et al 2008 [18] 
proceedings were included in the final analysis (fig 1 ). Of the selected 9 publications, 6 dealt with the development and implementation of novel US scores, while the other 3 focused on implementing MSUS in clinical practice, evaluating the usefulness of articular cartilage US assessment and the feasibility of sonography for intra-articular knee injections, respectively. The total number of patients involved was 1052, most of them (80.4\%) suffering from rheumatoid arthritis. Details about each of the selected studies' materials and methods are provided in Table I.

\section{Focus areas analysis}

Six out of the nine analysed studies focused on validating US scores and quantified feasibility as time spent for the US examination, disregarding any other feasibility related aspects [11,12,15-18]. In one of the studies, the main objective was to investigate the feasibility of US guided knee intra-articular injections [14], but in the results section the authors refer to feasibility exclusively as the accuracy of the technique. However, they also mentioned, presumably as characteristics of feasibility, 'convenience' and 'lack of radiation hazards', which we interpreted as outcomes addressing a few more of the previously proposed domains, namely acceptability and practicality. In the study comparing US cartilage scans with magnetic resonance imaging (MRI)-derived data [13], feasibility is seen only as the US-MRI correlation coefficient and US evaluation repeatability. The study that investigated the possibility of introducing MSUS in internal medicine residency [10] took into consideration aspects such as residents' training, cognitive skill set and competence evaluation, attending perception of the trainers and trainees (aspects pertaining to the implementation and practicality domains), but failed to consider any other feasibility area. Only 5 of the studies offered details regarding the equipment used and its technical characteristics [12$15,18]$, while almost all included an ample description of the assessed joints and features or structures [11-16,18].

The results of the semi-quantitative evaluation of the selected papers, as detailed in the Methods section above, are as follows: the highest score (3) was obtained by 6 of the papers $[10-12,15,17,18]$, while two publications scored one point each $[13,16]$ and one received 2 points [14]. Based on the set of focus areas previously mentioned, none of the works included in the final analysis practiced a systematic assessment of all feasibility domains, acquiring less than half of the maximum score we proposed.

\section{Discussions}

Our literature search revealed the fact that the feasibility of knee US techniques is poorly addressed, even though the knee is one of the most accessible joints and its US examination has been extensively studied. The time needed for evaluation represents in almost all cases the single feasibility related characteristic assessed, with authors dismissing several other important aspects of US daily practice implementation.

However, the current review is subject to several limitations. Our literature search was restricted to only 2 databases due to limited institutional access and spanned only over the last 10 years (considered most prolific in this area). We also did not include studies that focused on evaluating US feasibility for joints other than the knee, thus probably leading to a potential loss of information.

Additionally, the list of domains that need to be evaluated when employing a feasibility study was chosen based on a subjective appraisal of the available published methodology regarding this subject and on personal experience with US in daily practice, in the absence of standardized guidelines.

Although most of the publications included in the final analysis were studies that evaluated US scores, there was still a significant heterogeneity among these articles, given the restricted selection available, thus creating difficulties in using a subjective manner of evaluation. The purpose of the scoring method we proposed was to provide a useful straightforward alternative for the rapid evaluation of an article, taking into account the different types of US related papers. But due to the fact that we used a binary scoring system, we consider that many of the detailed aspects might be disregarded. As an example, we mention the first analysed article [10], where the authors mention briefly in the Introduction section the need for US in Internal Medicine residency - as an aspect of the Demand domain, but do not provide a more elaborate analysis of the extent to which knee US is likely to be used. However, we decided to score this area of focus with one point, while we gave no points for the Adaptation domain, even though the authors tackled this area by recommending further studies including more joints. Notwithstanding the low score this paper obtained (less than half of the maximum score and equal to the one given to other 5 different articles $[11,12,15,17$ $18]$ ), it is the only one of the publications we selected that took into account a wider range of feasibility aspects, closer to the way we envisage a MSUS feasibility study should be conducted. Moreover, the points given to the papers based on the study of US scores, were assigned mainly due to some overlap between two of the domain's outcomes of interest (inter-rater and intra-rater reliability, score sensitivity to change and assessment duration could represent outcomes of interest to both Implementation and Practicality) and the fact that we considered the US score testing itself as addressing the Demand domain. 
Despite the fact that we could not establish a threshold for the score we proposed and used, the relatively low results that were attained by assessing the publications support our conclusion, that MSUS studies currently lack an appropriate methodology for the systematic evaluation of the technique's feasibility.

In addition, the fact that only half of the papers offer equipment and technical features but none of them discuss machine availability or financial aspects, as acquisition, maintenance and consumable replacement, which are very important aspects in day to day practice. Also, with the exception of one study [10], none of the articles mention the experience or availability of the ultrasonographer, as part of a MSUS feasibility assessment.

Even with the above mentioned limitations, our review highlights the paucity of studies and guidelines concerning MSUS feasibility and suggests that this information gap should be properly addressed in future research, in order to ensure the correct place for MSUS in clinical practice.

\section{Conflict of interest: none}

\section{References}

1. Keen HI, Wakefield RJ, Conaghan PG. A systematic review of ultrasonography in osteoarthritis. Ann Rheum Dis 2009;68:611-619.

2. Karim Z, Wakefield RJ, Quinn M, et al. Validation and reproducibility of ultrasonography in the detection of synovitis in the knee: a comparison with arthroscopy and clinical examination. Arthritis Rheum 2004;50:387-394.

3. Nazarian LN. The top 10 reasons musculoskeletal sonography is an important complementary or alternative technique to MRI. AJR Am J Roentgenol 2008;190:1621-1626.

4. Naredo E, D'Agostino MA, Conaghan PG, et al. Current state of musculoskeletal ultrasound training and implementation in Europe: results of a survey of experts and scientific societies. Rheumatology (Oxford) 2010;49:2438-2443.

5. http://www.investopedia.com/terms/f/feasibility-study.asp (Last accessed on June $30^{\text {th }}$ 2016).

6. Lancaster GA, Dodd S, Williamson PR. Design and analysis of pilot studies: recommendations for good practice. J Eval Clin Pract 2004;10:307-312.
7. Arain M, Campbell MJ, Cooper CL, Lancaster GA. What is a pilot or feasibility study? A review of current practice and editorial policy. BMC Med Res Methodol 2010;10:67.

8. Tickle-Degnen L. Nuts and bolts of conducting feasibility studies. Am J Occup Ther 2013;67:171-176.

9. Bowen DJ, Kreuter M, Spring B, et al. How We Design Feasibility Studies. Am J Prev Med 2009;36:452-457.

10. Gulati G, Alweis R, George D. Musculoskeletal ultrasound in internal medicine residency - a feasibility study. J Community Hosp Intern Med Perspect 2015;5:27481.

11. Peiteado D, De Miguel E, Villalba A, Ordóñez MC, Castillo C, Martín-Mola E. Value of a short four-joint ultrasound test for gout diagnosis: a pilot study. Clin Exp Rheumatol 2012;30:830-837.

12. Perricone C, Ceccarelli F, Modesti M, et al. The 6-joint ultrasonographic assessment: a valid, sensitive-to-change and feasible method for evaluating joint inflammation in RA. Rheumatology (Oxford) 2012;51:866-873.

13. Ohashi S, Ohnishi I, Matsumoto T, et al. Measurement of articular cartilage thickness using a three-dimensional image reconstructed from B-mode ultrasonography mechanical scans feasibility study by comparison with MRI-derived data. Ultrasound Med Biol 2012;38:402-411.

14. Im SH, Lee SC, Park YB, Cho SR, Kim JC. Feasibility of sonography for intra-articular injections in the knee through a medial patellar portal. J Ultrasound Med 2009;28:14651470.

15. Ficjan A, Husic R, Gretler J, et al. Ultrasound composite scores for the assessment of inflammatory and structural pathologies in Psoriatic Arthritis (PsASon-Score). Arthritis Res Ther 2014;16:476.

16. Aga AB, Hammer HB, Lie E, et al. On behalf of the ARCTIC Working Group. Inflammation in early and established RA: a comparative study of different ultrasonographic joint assessments. Ann Rheum Dis 2014;73(Suppl2):652.

17. Hartung, W, Kellner H, Strunk J, et al. Development and evaluation of a novel ultrasound score for large joints in rheumatoid arthritis: one year of experience in daily clinical practice. Arthritis Care Res(Hoboken) 2012;64:675682.

18. Naredo E, Rodríguez M, Campos C, et al; Ultrasound Group of The Spanish Society of Rheumatology. Validity, reproducibility, and responsiveness of a twelve-joint simplified power doppler ultrasonographic assessment of joint inflammation in rheumatoid arthritis. Arthritis Rheum 2008;59:515-522. 